\title{
AN EYE FOR AN EYE AND THE STRUGGLE FOR POWER IN THE DISCOURSE OF THE EGYPTIAN ARAB SPRING
}

\author{
ALEXANDER BOGOMOLOV
}

\section{Introduction}

Among the slogans of the January 25, 2011 revolution in Egypt some were immediately picked up by the international media to become part of the globally recognizable image of the Egyptian Arab Spring. The most characteristic case in point is 'Bread, freedom, social justice and human dignity', which are often presented as the demands (mațālib) or goals (ahdāf) of the revolution. Meanwhile quite a few other slogans, reflecting even more closely the course of events on the ground, are less known internationally and lost in translation for the reasons of their idiosyncratic nature. One case in point is QIṢĀṢ (RETALIATION), which from the early days of the revolution featured among the most frequently voiced protestors' demands. According to a witness account, a popular chant al-qișās al- qișās ḍarbū iȟwatnā bi-r-rașaș (retaliation, retaliation, they hit our brothers with bullets) was first used immediately after the mass rally dubbed jum 'at al-gadab (Friday of Wrath), which occurred on the fourth day of the revolution (January 28, 2011), in which a large number of protestors (est. one thousand) were killed ${ }^{1}$. Ever since, many specific rallies included QIȘĀṢ as a key element of their names-slogans, e.g. a large demonstration on Friday July 8, 2011 held under the name of jum 'at al-qișass (the Friday of retaliation). Muhammad Mursi, Egypt's first post-revolutionary president also thematized

\footnotetext{
${ }^{1}$ Personal communication with Walaa Quisay, Oct. 2015, Warsaw.
} 
QIṢĀṢ in his public discourse ${ }^{2}$. The prominence of QIṢĀṢ as a revolutionary slogan was so high that a local observer noted: ata 'ajjib katīiran min hâal miṣr awwal marra fì ta'rīh ajid țawra mubniya 'alā al-qișāṣ (I am very much surprised at the state/situation of Egypt: [it is] the first time in my life that I find a revolution built on retaliation) ${ }^{3}$. The phrase tawrat al-qișās (revolution of retaliation) was used occasionally by the revolutionaries themselves, albeit not in reference to revolution in general ${ }^{4}$, but rather to some specific protest campaigns, which used QIȘĀṢ as a motto ${ }^{5}$. When the military deposed president Mursi, his supporters used the phrase tawrat al-qișăs in reference to the growing anti-coup protest movement ${ }^{6}$. At its core, QIȘĀṢ is a Sharia concept, reflecting the lex talionis principle, popularly known to Jews, Christians and Muslims alike as 'en eye for an eye'. However, as we shall try to demonstrate below it is far more than this, when it comes to the way the concepts functions in various types of discourses, including, notably, the one of the Egyptian Arab Spring.

We will begin our exposé of the concept's rather complex semantics with the analysis of most frequent attributive collocations with the noun qiṣs $\bar{s}$, adjectives 'ādil (just), sarī' (speedy, fast), 'ājil (immediate) and nājiz (prompt, complete), which appear to highlight the most idiosyncratic part of the concept. The first among these pairs clearly points to a connection that exists between QIȘĀS as key slogan of the revolution and the revolution's three big words, which we mentioned above, HURRIYA (FREEDOM), 'ADALA (JUSTICE) and KARĀMA (DIGNITY) ${ }^{7}$. Having analyzed the concept, we concluded that the discussion of QIṢĀṢ may help better understand what kind of JUSTICE the

${ }^{2} \mathrm{Cf}$. a characteristic media article of 2 June, 2012 titled 'Mursi committing to retaliate for the martyrs of the revolution' (murs̄ī yata'ahhad bi-1-qișāṣ li-šuhadā' at-tawra) on Al-Jazeera.net http://www.aljazeera.net/mob/f6451603-4dff-4ca1-9c10-122741d17432/ee5af389-1dbb-4835-b696$6146 \mathrm{cdd} 70$ af7

${ }^{3}$ The phrase is cited in an article titled Culture of Retaliation and Revenge (taqāfat al-qișās wa l-intiqām) by an Egyptian journalist Rola Kharsa published by an electronic publication al-Mișri al-Yawm, 14.2.2012 and is attributed to an unidentified 'socialist, friend' of the author http://m.almasryalyoum.com/news/details/52941

${ }^{4}$ which would be more often described as tawrat yanāyir (January Revolution) or the Revolution of Dignity.

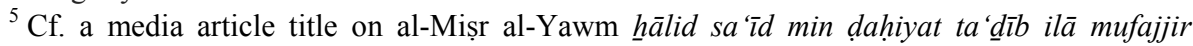
tawrat al-qișās min ad-dāhiliya (Khaled Said: from the victim of torture to the exploder of the revolution of retaliation against the [Ministry of] Interior) - http://m.almasryalyoum.com/news/ details/121627

${ }^{6}$ For some graphic imagery advertising August 2014 events tagged as Revolution of Retaliation see http://goo.gl/txoNuR.

${ }^{7}$ For a detailed analysis of the relationship that exists between QIȘĀS and 'goals' of the January 25 revolution other that JUSTICE, cf. Bogomolov, O.V. 2014. "Bread, dignity, justice and... retaliation: the concept of QIȘĀṢ and the values of the Egyptian revolution". The Oriental Studies (Skhidnyi Svit) 67. 20-38. 
revolutionaries wanted to achieve back in 2011. Then, we shall take a closer look at the notion of QIȘĀṢ in the Islamic religious discourses, particularly, the Sharia one, to which the concept owes much of its capacity to dominate and shape political discourse and its illocutionary power in the dispute over the political power. The manner, in which the Islamic legal discourse and the lay public discussion treat QIȘĀS is not identical and the points of both overlap and difference between the two discourses merit a closer analysis.

Our overall methodological approach is grounded in George Lakoff's conceptual metaphor theory ${ }^{8}$ and the Fillmorean frame-semantic analysis ${ }^{9}$. Each concept may be analyzed as a frame structure, i.e. a set of elements and relations among them, which may be described in terms of semantic roles (deep cases). We use the FrameNet ${ }^{10}$ project as a model in formulating frame descriptions matching our Arabic material. In discourse, however, concepts or frames that sustain them never appear as pure forms, but in a rather complex interaction with other concepts or frames. Patterns of such interactions appear as characteristic traits or marker of a particular strand of discourse. The Lakoffian notions of coherence $^{11}$ between metaphors and metaphorical entailment ${ }^{12}$ are the two most important ideas that we use as a guideline in explaining the interaction between different concepts/frames in the discourse.

\section{JUST retaliation}

QIṢĀSS often occurs in collocation with an attributive 'ádil (just). This is particularly characteristic for news items describing rallies demanding qișās $l i-\check{s}$-šuhad $\bar{a}$ ' (retaliation for the martyrs), cf.:

lam tamurr siwā sā'āt 'alā al-ḥukm ḥattā hnarajat masīra fī al-qāhira wa talathā ba'd yawm wāḥid muẓāhara fĩ al-iskandariya tunaddid bi-tahāwun wa tutạalib bi-qiṣāṣ 'âdil yušaddid 'uqūbat šurțiyeyn qatalā muwāṭinan dūna danb ${ }^{13}$

${ }^{8}$ Lakoff, G. and M. Johnson. 2003. Metaphors we live by. Chicago: The University of Chicago Press.

${ }^{9}$ Cf. Fillmore, C.J. 1985. "Frames and the semantics of understanding". Quaderni di Semantica VI. 2. 222-254.

${ }^{10}$ FrameNet is a web-based corpus, which draws on Charles J. Fillmore's frame semantics; the corpus contains descriptions of the internal structure of semantic frames referring to various situations, actions, events, cf. https://framenet.icsi.berkeley.edu/fndrupal/home

${ }^{11}$ Cf. Lakoff, G. and M. Johnson. 1981. Metaphors we live by. Chicago: The University of Chicago Press. 34, 59, 96.

${ }^{12}$ For the way Lakoff applies the term cf. Lakoff, G. and M. Johnson. 1981. Metaphors we live by. Chicago: The University of Chicago Press. 9, 12, 44, 91, 93, 94, 97, 102 etc.

${ }^{13} \mathrm{http}: / / \mathrm{m}$.almasryalyoum.com/news/details/121627 
[a few] hours had not passed since the verdict until a procession came out in Cairo and a demonstration followed it a day after in Alexandria denouncing complacency and demanding a just QIȘĀṢ [that would] strengthen punishment of the two policemen [who] killed an innocent (lit. without guilt) citizen

While as of mid-January 2015 Google search returned 31,600 results for al-qișass al-'ádil (the just retaliation, def. form), the indefinite form qiṣaș 'a dil ([a] just retaliation) returned only 3,570 results ${ }^{14}$. The phrase does not accept negation except for a very specific set of contexts. The Google search for standard negation al-qișās gayr al- 'ádil has returned no results, while for the indefinite form qișās gayr 'âdil it showed only 8 results. Syntactically, the definite form in Arabic mostly functions as direct object, subject, or a Genitive attribute (e.g. jum 'at al-qișās al- 'âdil - Friday of just retaliation), while the indefinite one appears in the predicative position ${ }^{15}$. In the latter case, the sentences are structured as $X$ [is] a just retaliation for $Y$. Less frequent are cases with indefinite qișa ș featuring in Genitive case after a preposition, e.g. $90 \% \mathrm{~min}$ jarāim al-qatl al-mumanhaj li-ș-ṣuhufiȳn dūna qișās $(90 \%$ of systematic murder crimes of journalists [are left] without retaliation) ${ }^{16}$. Syntactic limitation on the use of negation with the phrase does not appear to be the only one. The cases where negation does occur are limited pragmatically to ironic and polemical contexts. These observations lead us to the following conclusions: (1) the notion of JUSTICE is part of the semantic structure of QIȘĀS and the adjective 'ádil (just) is used as attributive with qișās merely to reinforce this meaning component - (al)- qișās (al)- 'ádil is not a type (a subset) of QIȘĀṢ, but QIȘĀṢ proper, the attribute 'ádil in the discourse only serves pragmatic purposes ${ }^{17}$; (2) QIṢĀS features about ten times more often as a subject of demand compared to factual statements, i.e., speakers are ten times more likely to ask for QIȘĀṢ then to assert that it has actually been performed.

While we have being writing this piece, a dramatic change has occurred in the Google search counts for one of the collocations that we study in this paper, which happened within a period of slightly over one month. As of 24 February, 2015, the score for the indefinite form of the noun phrase qișās 'a dil (just QIȘĀṢ) went up to 69,300 results, while for the definite form it showed only an

\footnotetext{
${ }^{14}$ All searches cited in this article are limited to Egyptian web resources only.

${ }^{15} \mathrm{We}$ have discounted from our analysis the Accusative case indefinite form, which functions as a direct object, for it is graphically different from Nominative and Genitive case forms (it has the letter 'alif at the end of each word).

${ }^{16}$ A news article title on al-Yawm as-Sābi‘ newspaper - http://goo.gl/m6A5c6

${ }^{17}$ For instance in the above example the illocutionary point is the demand for a stronger punishment, which is based on the presupposition that just (i.e. proper) QIṢĀṢ is the one that is strong enough.
} 
insignificant increase (33,100 results). The updated figure for the indefinite form includes 1,370 reposts of essentially the same news item quoting a Twitter post by an Egyptian oppositional politician Hamdin Sabāhī on the Egyptian air force retaliatory attack on ISIS in Libya ${ }^{18}$. The nature of many other more recent posts

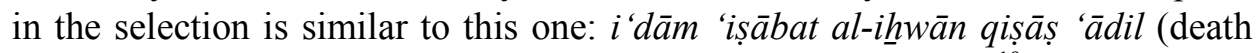
penalty for the [Muslim] Brotherhood gang is a just retaliation) ${ }^{19}$; $i$ 'dām qatalat dubāt kardāsa qișās 'ádil min al-qad̄a' (death penalty for the killers of officers of Kerdasa is a just retaliation from the judiciary $)^{20}$. For all their relative scarcity, entries with the indefinite form related to President Mursi period are simi$\operatorname{lar}^{21}$, they all are meant to promote an image of a government capable of delivering justice. The 20-fold increase in texts asserting that QIȘĀṢ has been performed compared to effective decline in the number of texts demanding QIȘĀS to be performed ${ }^{22}$ appear to signify the change in discourse formation: the rapid come back of the old authoritarian self-congratulatory rhetoric that had dominated the public discussion during the Mubarak period.

Many contexts could be found, where qișās and 'idāla (justice) feature as fully synonymous nominations, cf. the following two quotations from the same source referring to the same piece of news:

(1) 90\% min jarāim al-qatl al-mumanhaj li-ṣ-ṣuḥufiyīn dūna qișāṣ - 90\% of systematic murder crimes of journalists [are left] without retaliation;

(2) ... inna al-amr al-akțar ițāratan li-l-qalaq yakmun fĩ al-iḥṣā'iyāt aṣ-șādira 'an al-lajna ad-duwaliya li-ḥimāyat aṣ-ṣuḥufiyīn bi-anna $90 \%$ min al-qatala lam yatimm taqdīmuhum li-1-'idāla\

${ }^{18}$ The significance of the Twitter post that could have led to its reprinting by every media outlet in Egypt may be attributed to the fact that a well-known politician with revolutionary credentials and a certified opponent of Husnī Mubārak's regime was now congratulating the Air Force, and by extension the president Sīsī's regime.

${ }^{19}$ A news article title heading dated 28 April 2014, on al-Wafd website citing a local 'political activist' Muhammad Abū-Hāmid praising the verdict of Minya governorate court in Upper Egypt, which issued 37 death and 491 life imprisonment sentences for members and supporters of Muslim Brotherhood - http://goo.gl/ANaHz1

${ }^{20}$ A news article title heading dated 3 February, 2015 on Mișr al-Balad website praising the death sentence for 183 defendants in the case of an assault on district police station at the village of Kerdasa, Giza governorate - http://misralbalad.com/page.php?id=25493\#.VO3yP3yUcT8

${ }^{21} \mathrm{Cf}$. news article titled islām aš-šătir: hukm majzarat būr sa 'ìd qiṣāṣ 'ādil (Islam aš-Šāṭir: the verdict on Port Said slaughter is a just retaliation) dated 26 January 2013 on Masress website $\mathrm{http} / / / \mathrm{www}$.masress.com/alnahar/102280

${ }^{22}$ The little growth in the number of definite form al-qișās al- 'âdil occurrences effectively means that almost no new cases have been registered by the search engine during the period under review. 
... the most troubling matter lies in statistics issued by the International Committee for the protection of journalists [which say] that $90 \%$ of killers have not been brought to justice $^{23}$.

It is obvious that the phrase taqdìm li-l- 'adāla (bringing to justice) and qișās in the two segments refer to the same event, and, hence, 'adāla and qișāṣ in this context are treated by the author as fully synonymous. The cited news article is largely based on an English original, which allows to match Arabic to sourcelanguage nominations: dūna qișās matches the phrase 'get away with it', ' $90 \%$ min al-qatala lam yatimm taqdimuhum li-l-'adäla' corresponds to the English phrase ' $90 \%$ of murderers walking free', while the English segment ' 370 journalists have been murdered in direct retaliation for their work' has been translated as '370 șuhufiyan qutilū (...) fì-intiqām mubāšir li-qiyāmihim bi- 'amalihim ${ }^{24}$. In the latter segment, an apparent negative evaluation embedded in the English word retaliation has prompted the Arab journalist to refrain from translating it as qișās, and to use Arabic intiqām (revenge) instead ${ }^{25}$.

In the following paragraph QIȘĀṢ is not only contrasted to the notion of (in)JUSTICE expressed as $z u l m^{26}$, but appears to be somewhat superior to 'adāla, which in this context is used in a more narrow sense (criminal prosecution), cf.:

'indamā yaț̣āa az-ẓulm wa tata'ahhhar al- 'adāla, ḥīnamā yaġīb mabda' al-qiṣāṣ li-yatalāšī aš-šu'ūr bi-l-amn ḥinnamā yatakarrar al-ḥādit wa lā yataḥarrak aḥad lā tandahiš hịnamā tarā al-muwāținīn wa qad taḥawwalū li-quḍāt wa jallādīn fì al-waqt nafsihi li-tasūd šarī'at al-ḡāb bayn an-nās ${ }^{27}$

When the injustice is excessive, and justice is late, when the law disappears, and the principle of $Q I S T \bar{A} S$ is obliterated so that the feeling of security vanishes, when the incident is repeated and no one moves, don't be surprised when you see citizens having turned into judges and executioners at the same time, so that the law of the jungle prevails among the people.

${ }^{23}$ Both quotations have been borrowed from the same article published on al-Yawm as-Sābi', 3 Nov. 2014, the $1^{\text {st }}$ quotation represents the title of the article - http://goo.gl/kZrUp0

${ }^{24}$ For the original English text see article ' $90 \%$ of journalists' murderers across the world get away with it - report', The Guardian, 28 October 2014 - http://www.theguardian.com/media/ greenslade/2014/oct/28/journalist-safety-press-freedom

${ }^{25}$ Note also the rendition of qișās as 'legal retribution' in the pious English translation of the Quran (Saheeh - http://quran.com/2).

${ }^{26}$ There are several nominations in Arabic that express this idea with zulm being perhaps the most comprehensive one and very common in the religious discourse.

${ }^{27}$ A feature article titled intiqām al-ahālì min al-baltagiya (people's revenge against thugs) published on al-Ahrām al-Yawmī on 8 September 2012 - http://digital.ahram.org.eg/articles.aspx? Serial $=1122056 \&$ eid $=837$ 
QIȘĀS here concludes a list of nominations representing various aspects of JUSTICE and is even elevated to the status of an overarching principle of some sort.

\section{SPEEDY retaliation}

There is ample linguistic evidence both within what we have described as the discourse of the Egyptian revolution and in other genres of Arabic texts that QIȘĀS is expected to be performed in a speedy manner. Procrastination in the dispensation of justice, on the contrary, is often described as harmful to social peace and an incentive to further growth of crime. The discourse of the Arab Spring seems to pay far less attention to the notion of the quality of justice and attendant costs of ensuring such quality, including, notably, the time costs. The demand for a speedy QIȘĀS is a frequent occurrence in the language of political slogans during 2011-2013 Egyptian street protest, cf.:

wa țâlab al-mutazāhirūn bi-dawla madaniya wa qișāṣ sarī‘ min al-qatala wa al-fāsidīn and taṭhir ajhizat ad-dawla... ${ }^{28}$

and the demonstrators demanded a civil state and speedy QIṢĀṢ against the killers and corruptionists and cleaning the state agencies...

Aside from $\operatorname{sarl}^{-}$(fast, speedy) there are at least two other adjectives that frequently co-occur with QIȘĀṢ in the revolutionary discourse: 'ájil (fast, immediate) and najjiz (full, complete, prompt). The semantic difference between the three adjectives is slight and the fact that they add almost nothing to the meaning of each other is attested by a rather infrequent co-occurrence of any two of these adjectives in collocation with QIȘĀṢ ${ }^{29}$. Cf. a few examples:

qālat ad-duktūra Karīma al-Ḥafanāwī inna dimā’ šuhadā’ tawrat 25 yanāyir lan taḍī‘ muš̄iratan ilā annahum mustamirrūn min ajl qișāṣ 'ājil min mubārak allad̄ī yajib an yuhākam 'alā kull aš-šuhadā' allad̄ina saqațū fị tawrat yanāyir ${ }^{30}$

${ }^{28}$ Quotation from a news article on al-Mișrī al-Yawm newspaper, dated 8 August 2011, enumerating three standard demands of the January 25, 2011 revolution that would appear on placards held by protesters - http://www.almasryalyoum.com/news/details/102540

${ }^{29}$ Google search has returned 5 results for al-qișāṣ as-sarī ${ }^{\top}$ wa an-nājiz; 6 for al-qișāṣ assarī' wa al- 'ājill; 2 for al-qișāṣ an-nājiz wa al- 'äjil and 49 for al-qișāṣ al- 'ājil wa an-nājiz, which may be accounted for by the fact that nājiz has additional meaning component (complete), while the other two only express slightly different aspects of temporality.

${ }^{30}$ An appearance on at-Ṭarīq TV channel by a prominent politician a co-founder of Kyfāya movement and the National Association for Change Karīma al-Ḥafanāwī - dated 13 August 2014 - i.e. just a weak before a highly contested 20 August retrial of former President Mubarak $\mathrm{http} / / / \mathrm{www}$. atvsat.com/latest-news/item/53021 
Dr. Karīma al-Hafanāwī said that the blood of martyrs of January 25 revolution will not be wasted, having pointed out that they (probably in reference to her political party $-A$.) continue for the sake of an immediate QIȘĀṢ against Mubarak who has to be tried for all the martyrs who fell in January 25 revolution.

The adjective 'ajil probably conveys the idea of urgency as compared to other adjective on our list. The phrase al-qișās 'ajjil often occur in texts justifying political violence. Echoing the famous Islamist slogan Isläm huwa al-hall (Islam is the solution), an article titled al-qișāṣ al-'ajil huwa al-hall (immediate QIȘĀṢ is the solution) calls for sur'at tațbìq al-qānūn (a speedy application of law) over the members of anti-government Islamist rebellion in Sinai underscoring the urgency of the matter by claiming that la badīla siwā an taqūm ad-dawla bi-d-darb bi-yad min hadìd li-l-qaḍà' 'alayhim (there is no choice but for the state to deal a blow by a fist [lit. hand] of iron to get done with them) ${ }^{31}$. Speediness of QIȘĀṢ also implies simplicity, cf.:

badlan min an yakūn al-qișāṣ an-nājiz aysar ahdāf at-tawra wa asra 'ahā taḥaqquqan waqa' tunā’ī al-ḥukm al-'askarī wa al-madanī fì hূața' fādiḥ 'indamā ta 'āmal ma'a malaff jarā'im rumūz al-'ahd al-bā'id bad'an bi-ra's an-nizāam husnī mubārak wa intihā'an bi-aḍnābihi min al-balțajiya wa șug̉ār al-fāsidīn kamā law kān ta āamal ma'a jarīmat našl waqa'at fị utubīs naql 'ām aw hāadit murūr... ${ }^{32}$

Instead of [for] the prompt QIȘĀṢ to be the easiest and the speediest among the goals of the revolution in achievement, the military civilian duumvirate fell into a fatal error when [it] treated the file of crimes of the symbols ${ }^{33}$ of the bygone era beginning with the head of the regime Hosni Mubarak and ending with its tails including the thugs ${ }^{34}$ and small corruptionists as if it [would be] treating a crime of pickpocketing that happened on a public bus or a traffic accident...

It is characteristic not only of this example but of the entire sample that we have assembled for the purposes of this study using collocations of qișās with adjectives 'ādil (just), sarī' (speedy), nājiz (complete, prompt) that they all appear to be built on a presupposition that the nature of crime is clear and there is no doubt whatsoever as to who is the offender.

The adjective nājiz (complete, prompt) is semantically somewhat more complicated compared to the former two adjectives. The source meaning of the root

${ }^{31}$ An op-ed published on al-Ahrām daily newspaper on 25 November 2014 - http://digital. ahram.org.eg/Community.aspx?Serial $=1726025$

${ }^{32}$ From an op-ed article with a characteristic title al-Qiṣāṣ Tațhīr and Iṣlāḥ (QIȘĀṢ - cleansing and reform/improvement) dated 7 July, 2011 - http://www.shorouknews.com/columns/view. aspx?cdate $=07072011 \& \mathrm{id}=51006460-\mathrm{fb} 78-48 \mathrm{aa}-9 \mathrm{fad}-\mathrm{a} 6671 \mathrm{a} 551 \mathrm{fb} 8$

${ }^{33}$ The idiom rumūz (symbols) of smth. e.g. regime, political organization, historic period is used in reference to leaders and most prominent figures associated with some entity or period.

${ }^{34}$ see footnore 26 above. 
$n-j-z$ is 'accomplish, fulfill, complete', the temporal semantics is part of the presupposition: whatever has been completed must have had some length, which by completion was cut short, hence the idea of promptness. Cf.:

inna al-'adāla al-intiqāliyya yajib an tatimm 'abra qānūn wa laysa hadafuhā al-intiqām bal, qișās nājiz yurīḥ qulūb ahālī aš-šuhadā’ wa al-mawjū ‘̄in... ${ }^{35}$

The transitional justice has to be performed through law and its goal is not revenge but complete (prompt) QIȘĀṢ [that would] relieve families of martyrs and those who feel pain (lit. pained ones)...

Here the adjective nājiz is used to reinforce the meaning, which is already part of QIȘĀṢ semantics, i.e. the capacity to bring (prompt or complete) relief from moral pain ${ }^{36}$.

All three adjectives do not function as definitive attributes but rather as intensifiers, to the idea of speediness that is embedded in the semantics of QIȘĀST. The adjectives in collocation with the noun qișās do not accept negation: phrases *qișās gayr sarī' or *qișās gayr 'ajjil have returned no results on Google search, while al-qișās al-muta'ah̆hir (the delayed QIȘĀṢ def.) showed 3 and qișaș muta 'ahhirir (delayed QIȘĀS indef.) - only one result, which renders them rather anomalous. A speedy QIȘĀṢ, hence, is not a type of QIṢĀṢ but rather QIȘĀṢ proper, same as just QIȘĀṢ. Consider also the following example: inna al-qișās ș min al-mujrimīn huwa aqșar at-țuruq li-tațhīr al-bilād min al-fasād (QIȘĀṢ against (lit. from) the criminals [is] the shortest way of clearing the country from corruption) ${ }^{37}$. The phrase, which contains no attribute explicitly conveying the idea of speediness is obviously built on a presupposition that may be formulated as: it takes little time to perform qiṣass or, in other words, qiṣaș is speedy. In line with this presupposition, QIȘĀS is presented in the cited text as some sort of magic bullet - an instrument that may bring about a quick solution to complicated (and notably, protracted) social problems.

It is notable as well that the notion of speediness in relation to justice does not seem to a have a negative connotation. An April 6 movement activist, 'Alā' 'Abd-ul-Fattāh, along with 25 others was arrested for protesting against the newly re-introduced restrictions on the freedom of assembly in the early post-coup

${ }^{35}$ News article dated 5 August 2014, titled Sabāhī: attafaq ma'a qānūn 'adāla intiqāliyya lā intiqāmiyya aw intiqā'iyya (Sabahi: I agree with the law on transitional justice, not the revengeful nor the selective [one]') - http://www.almasryalyoum.com/news/details/442821

${ }^{36}$ The idea that pains of victim's relatives must be relieved and QIȘĀS is designed to be the best means to that purpose, is essential for the Islamic legal discourse on the matters of retaliation, as we shall see below.

${ }^{37}$ From an op-ed article with a characteristic title al-Qișāṣ Tațhīr and Ișlāḥ (QIṢĀṢ [is] cleansing and reform/improvement) dated 7 July, 2011 - http://www.shorouknews.com/columns/ view.asp $x$ ?cdate $=07072011 \& \mathrm{id}=51006460-\mathrm{fb} 78-48 \mathrm{aa}-9 \mathrm{fad}-\mathrm{a} 6671 \mathrm{a} 551 \mathrm{fb} 8$ 
Egypt $^{38}$. The activists were then submitted to al-muhākama al-'ájila (speedy trial $^{39}$ and the activist's mother commented on it saying: la yūjid ladaynā qaḍa

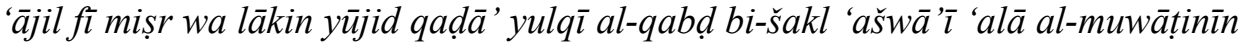
(there is no speedy/immediate discharge of justice in Egypt, but there is justice that randomly arrests citizens). Obviously the two parts of the utterance are contrasted as normative/commendable vs. abnormal/deplorable, and the first part is based on a presupposition that speedy Justice is good. The belief in the speedy QIȘĀS stays as a positive value, of course, is very idiosyncratic idea. For instance, it sharply contrasts with the European idea of revenge as a dish best served cold ${ }^{40}$.

In the media discourse, the demand for a speedy QIȘĀṢ is often contrasted to the description of justice system as prone to procrastination. Specific lexis combining temporal semantics with negative evaluation such as taq'a $u s$ (sluggishness, failure to do something) often feature in such contexts, cf:

al-taqā 'us fì jam‘ adillat qatl aš-šuhadā' hattā ba'd al-i'lān ad-dastūrī yu'akkid ḍu'f rag̉bat man bi-s-sulța fĩ al-qiṣāṣ ${ }^{41}$

Sluggishness in collecting evidence of the killing of martyrs even after the Constitutional Declaration confirms the weakness of desire [on the part] of [those] who are in power in [performing] QIȘĀṢ.

The idea of the desirability of speediness may feature in a text discussing justice even without QIȘĀṢ being explicitly mentioned, cf.:

... fa-qīmat al-'adl ta 'lū wa tazīd wa tastaqirr fĩ damīr al-mujtama' 'indamā ta'tī ạ̣kām al-qaḍā' nājiza sarī'a lā yuqayyiduhā tabāṭī al-ijră’āt wa lā tu'aț̣iluhā 'aqabāt šakliya aw mu'awwiqāt 'amaliyya. ${ }^{42}$

${ }^{38}$ The story is related in a news article titled iḥālat 26 nāšitan siyāsiyyan baynahum Alā 'Abd-ul-Fattāh wa Ahmad Māhir li-muhākama 'äjila (the transfer of 26 political activists among them Alā' 'Abd-ul-Fattāḥ and Aḥmad Māhir to a speedy trial) published on 2 December 2013 http://www.masress.com/fjp/98669 ; for mother's comments dated 14 March, 2014 published on al-Badīl website see http://goo.gl/MR60yw

${ }^{39}$ This term frequently occurs in the 2011-2015 Egyptian media texts $(19,800$ results on Google search for muhākama 'ājila -and 5,610 for al-muhākama al-‘ājila), it is essentially a technical term used in reference to an abridged procedure applied in simple cases and has nothing to do with the notion of speedy trial in the Western legal tradition as discussed below.

${ }^{40}$ The saying is often described as an English proverb, while its origins are traced to French literary sources, whatever the origin, the phrase appears to have stricken a chord with all European cultures and expresses a commonly shared belief.

${ }^{41}$ The phrase is attributed to the relatives of martyrs killed during January 2011 events - published on December 17, 2012 - http://albedaiah.com/node/11586

${ }^{42}$ An op-ed article dated 17 January 2013 - http://www.gamalnassar.com/main/art.php?id= $6 \& \operatorname{art}=632$ 
... for the value of justice goes up and increases and stabilizes in the conscientiousness of the society when the verdicts of judiciary come prompt and speedy, and the slowness of procedures does not restrict them and formal obstacles and practical impediments do not disrupt them.

This contraposition between the speedy QISTĀṢ and sluggish formal justice system, a recurring theme in the discourse of the revolution, contributes to creating tensions between the notions of (formal) JUSTICE and QIȘĀS. The formal justice system may also be presented as merely an instrument for performing QIṢĀṢ, cf.:

kamā akkad 'alā ḍarūrat taḥqīq al-'adāla wa ittihāạ al-ijrā'āt wa sann al-qawānīn allāzima wa as-sarī'a fĩ al-qișās kay tabrud qulūb ahālī aš-šuhadā' wa yataḥaqqaq al-itsqrār al-manšūd ${ }^{43}$

[He] also stressed the need to implement justice and take measures and adopt the necessary and speedy laws on QIȘĀṢ in order for the hearts of the relatives of martyrs to cool down and the desired stability to be achieved.

Note the metaphoric 'hot hearts', which are supposed to be cooled by QIȘĀṢ. The causative link between the notion of HEAT and speedy action could also be illustrated by examples from other contexts: a rubric on urgent matters in a media publication, for instance, may be called qaḍaya sāhina (hot issues) ${ }^{44}$.

While the notion of justice delayed as justice denied in the English-language debate on justice, seems to be similar to the idea of immediacy associated with QIṢĀS in Arabic, there is a significant difference between the two. Different frame elements including both the core and non-core ones are foregrounded in the English (and generally Western) discussion on timely justice. Trial is the key locus and instrument of Justice in the English-language notion of the speediness of Justice. It is also notable that speediness in the Western legal tradition is seen as serving the interests of the defendant ${ }^{45}$, while the QIṢĀS-centered discussion strongly foregrounds Punishment as the outcome of the process and the Victim and the Victim's next of kin as the key protagonists. Cf.:

al-qișāṣ al-‘ājil yā siyādat ar-ra'īs ya'nī ḥaqq ahālī aš-šuhadā’ wa laysa amwāl wa ḥajj wa 'umra wa ta'wīsọāt ${ }^{46}$

${ }^{43}$ From an article on Mișr 11 website (www.masr11.com), the quotation is attributed to a 'political analyst' Muḥsin Šalabī - http://goo.gl/8L 8afM

${ }^{44} \mathrm{See}$ http://albedaiah.com/node/11586 for an article under this rubric. We will return to the discussion of the supposed soothing effects of retaliation in the section (4) on QIȘĀṢ in the Islamic normative discourse.

${ }^{45} \mathrm{Cf}$. the notion of speedy trial in the US Constitution Sixth Amendment.

${ }^{46}$ The phrase is attributed to Karīma al-Hafnāwī, a member of the oppositional National Association for Change and Social Justice Alliance http://www.cairoportal.com/story/126174 
The immediate QIȘĀṢ, Mr. President, is a right of the relatives of the martyrs and not money and hajj and umra ${ }^{47}$ and compensations.

QIṢĀS is presented here as serving the interests of victim's next of kin first and foremost. It also appears to be superior to other, milder, forms of justice.

A frequently reoccurring theme in the revolutionary discourse is the idea that the adjudication of cases, which emerged in the context of the revolution, should be speeded up to ensure a speedy QIȘĀST, which is seen as essential for the progress of Revolution - an instrument that will quickly move the Egyptian society from the past to a better future. Cf.:

kull mā narjū taḥṣị̣ dawā'ir kāfiya tatafarrag li-naẓr hādihi al-qaḍāyā min ajl sur'at al-injāz l-ig̀lāq malaffāt al-māḍ̄ wa at-tawajjuh naḥwa al-mustaqbal al-af̣̣al bi-dni-llāh ${ }^{48}$

All what we ask for [is] to designate sufficient [number of] departments [specifically] dedicated to the review of these cases for the speediness of delivery and in order to close the files of the past and turn toward the better future with God's permission.

Here is the same idea expressed in a slightly different manner:

nurīd $a s$-sur 'a fī taḥqīq al-'adāla wa al-qișāṣ li-kay narmī halfa ẓahrinā hādihi al-ḥiqba al-bagīịa min tārīh miṣr wa li-nakšif 'an sawā'idinā wa na'mal 'alā raf' miṣr min hād̄ā al-ḥaḍị̣ allad̄ī ag̉raqa miṣr fî al-fasād wa al-mufsidīnn ${ }^{49}$.

We want speed in ensuring justice and QIȘĀṢ in order to throw behind our backs this abhorrent era of Egypt's history and roll up our sleeves and work on raising Egypt from this abyss which has drowned Egypt in corruption and corruptionists.

In this context a speedy QIȘĀSS apparently lends its momentum to the Revolution, which is understood as a purposeful forward-going movement of the Egyptian people ${ }^{50}$. QIȘĀṢ may even be presented as an instrument of a broad social reform:

kamā anna al-qiṣạṣ iṣlạḥ li-anna isti'șāl al-fāsīdīn wa al-mujrimīn ya'nī tajhīz al-arḍ li-waḍ‘ asās al-binā' as-salīm min nāḥiya wa yuwajjih risālat rad' li-ayy mas 'ūl

${ }^{47}$ Hajj is a regular annual pilgrimage to Mecca also one of the five pillars of Islam (duty of every able-bodied Muslim who can afford it to be performed at least once in a lifetime), Umrah is a non-compulsory irregular minor pilgrimage; al-Hafnāwī is referring to a practice of sponsoring pilgrimage to holy places as a type of award or compensation by the government.

${ }^{48}$ From an article published in al-Ahrām newspaper on 17 July 2011 titled kalimat haqq (A Word of Truth) http://www.ahram.org.eg/archive/Columns/News/90086.aspx

${ }^{49} \mathrm{http}: / /$ www.egyptianoasis.net/showthread.php?t=58345

${ }^{50} \mathrm{Cf}$. Bogomolov, A. 2014. "Constructing political other in the discourse of the Egyptian Arab Spring”. Scripta Neophilologica Posnaniensia XIV. 29. 
turāwidūhu nafsuhu 'alā al-fasād ba'd an yata'akkad inna miqșalat al-muhāsiba mawjūda wa tantazir raqabat ayy fāsid ${ }^{51}$.

QIȘASS [is] also reform for the eradication of corruptionists and criminal means the preparation of ground for laying the foundation for a healthy (also whole and sound $A . B$.) construction on the one hand and [it] sends a message of deterrence to any official [whose] soul/self is tempting him to [engage in] corruption as he is convinced that the guillotine of accountability exists and is waiting for the neck of any corruptionist.

From that perspective it is clear why a prominent revolutionary Islamic preacher Maẓhar Šāhīn named an immediate QIȘĀṢ the most important among the revolutionary demands:

naḥnu mustamirrūn fī tawratinā ḥattā taḥqīq jamī' al-mațālib wa 'alā ra'sihā al-qiṣasṣ $a l-\bar{a}_{j} i l^{52}$

we continue our revolution until the fulfillment of all our demands and foremost (lit. at the head of them) among them the immediate QIȘĀS

\section{QIȘĀṢ in the Islamic normative discourse}

Sharia norms on retaliation are based on lex talionis principle, which calls for a full qualitative commensurability of punishment with injury inflicted on the victim of a violent crime captured in the well-known idiom 'an eye for an eye ${ }^{, 53}$. The Islamic legal literature on QIȘĀṢ is voluminous and instead of going into detailed discussion of it, we will focus only on a few aspects of this normative discourse most often cited by the contemporary Muslim apologists of a Shariabased legislation, which appear to be quite idiosyncratic and significant for understanding the semantic structure of the concept. Each particular point will be presented as a link to other concepts and ideas, which are usually used to make sense of QIṢ̄̄Ṣ.

4.1 HEALING and PREVENTION: QIȘĀṢ is presented in the Islamic normative discourse as a method of healing the pains of people affected by

\footnotetext{
${ }^{51}$ From an op-ed article with a characteristic title al-Qiṣāṣ Tațhīr and Iṣlāḥ (QIṢĀṢ - cleansing and reform/improvement) dated 7 July, 2011 - http://www.shorouknews.com/columns/ view.aspx ?cdate $=07072011 \& \mathrm{id}=51006460$-fb $78-48 \mathrm{aa}-9$ fad-a6671 a551 fb8

52 The phrase is attributed to a prominent revolutionary Islamic preacher Maẓhar Šāhīn http://www. el-balad.com/154193.aspx

${ }^{53}$ The source of the idiom in the European languages is the Hebrew Bible (Exodus 21: 23-25, Leviticus 24: 19-21, Deuteronomy 19: 20-21); the Quran explicitly refers to the Biblical antecedent (Quran 5: 44, 45); the Babylonian law and the Medieval European legal systems, such as the Salic law and the [Kievan] Russian Justice are also exemplify lex talionis systems.
} 
crime, such as relatives of the victim and the community at large, and preventing further crimes:

wa al-qișāṣ huwa fi'l mujnī 'alayhi aw fi'l waliyihi bi-jānin mitla fi'lihi aw šibhahu, wa hikmatuhu at-tašaffi wa bard harārat al-ġayz; wa qad šarra'a aḷ̣āhu al-qișāṣ zajran 'an al-'udwān wa istidrākan lamā fī an-nufūs, wa iḍāqatan li-l-jānī mā ad̄āqahu al-mujn̄̄ 'alayhi, wa fĩhi baqā' wa ḥayāt an-naw' al-insānn̄ ${ }^{54}$.

and QIȘĀṢ is an act of the injured party or the act of his executor ${ }^{55}$ [in respect] to the offender same as his act or similar [to] it, and its wisdom [is] the healing and cooling the heat of anger; and Allah has legislated QIȘĀS to rein in agression and anticipate (forstall, redress) for what [is] in the souls, and let the offender taste what he let taste the injured party, and in it [is] the survival and life of the human kind.

The $5^{\text {th }}$ form of the verb tašaffā - (to be cured, healed, restored to health) features in similar contexts at least as early as the time of writing of the classical Arabic dictionary Lisān al-'Arab (13 cent. AD) ${ }^{56}$. The notion of healing is not limited to QIȘĀS alone and since long was associated with the whole set of lexis belonging to the semantic field of Revenge, cf. a verse cited in Lisān al-'Arab under the entry $\underline{t} a^{\prime} r$ (revenge): šafaytu bihi nafsī wa adraktu tú ${ }^{\prime} r a t t^{57}$ (I healed myself by him - i.e. by killing him - and realized my revenge). The long association between tašaff (healing) and the semantic field of Revenge has led to the former acquiring such a strong connotation with the latter than in modern usage, particularly, the vernacular one, it functions as a synonym of revenge. This meaning found its way into the European dictionaries of Arabic, e.g the English

\footnotetext{
${ }^{54}$ Șāliḥ bin Fawzān bin 'Abdullah al-Fawzān. al-Mulahַhaṣ̣ al-Fiqhī. Dār al-'Āṣima. ar-Riyāọ. 1423 h., part 2, p. 476 http://shamela.ws/browse.php/book-11811/page-895

${ }^{55}$ For the sake of simplicity, in this paper, we have opted for one of the translations used by Lane in his classical Lexicon, executor, as a match for the difficult Islamic concept of wali, whenever wali ad-dam (see below) is meant - cf. Edward William Lane. An Arabic-English Lexicon. Beirut, Lebanon: Librairie du Liban. 1980/1997; the noun wali stems from the verb waliya (to be near, adjoin, follow; rule, govern), derivatives of the stem (e.g. the $5^{\text {th }}$ form tawallā) also convey the idea of possession, hence, wali ad-dam - 'next of kin, who possesses the blood of a slain relative', meaning 'having the right to kill his offender', wali al-amr - 'the one who possesses the [right to deliberate on] affairs', which, depending on the context, means either a legal guardian or a ruler, see also footnote 34 below.

${ }^{56} \mathrm{Cf}$. the following usage under the entry šafā in Lisān: tašaffaytu min al-gayz (I cured [myself] from wrath); and particularly, wa yaqūl al-qā'il minhum: tašaffaytu min fulān id̄ā ankā $f i$ 'aduwwihi nikāyatan tasurruhu (and some of them say: I cured myself from someone if [he] hurt his enemy in a manner that makes him happy; in later usage nikāya also means 'revenge') - Ibn Manz̄ūr. Lisān al-'arab. Beirut: Dār Șādir, 1955-1956, 15 vols.

${ }^{57}$ Here the reflexive meaning, same as that of the $5^{\text {th }}$ form, is realized at the lexical level through the reflexive auxiliary phrase nafsi (myself, lit. my soul), revealing the source meaning of the stem 'heal' even more - Ibn Manẓūr. Lisān al-'arab. Beirut: Dār Șādir, 1955-1956, 15 vols.
} 
edition of Hans Wehr's dictionary provides the following definition of tašaffä: 'to take revenge, avenge oneself, satisfy one's thirst for revenge, vent one's anger, take it out ( $\min$ on) ${ }^{,} .{ }^{58}$ The original meaning of the $5^{\text {th }}$ form shared with other derivatives of the stem, has nevertheless remained transparent for the speakers.

The link between QIṢĀṢ and tašaffi that comes out most explicitly in the Islamic normative discourse points to a wider cultural landscape, within which the concept of QIȘĀS is situated. This landscape, among other things, includes a belief that certain events (violent crimes among them) generate powerful negative emotions that could be compared to sickness. The notion of istidrāk lama fi an-nufüs (anticipation for what [is] in the souls), which is offered as part of the rationale for QIȘĀS, also appears to be quite informative for the reconstruction of this cultural background. The plural form nufüs suggests that a negative mental or emotional process may also be going on in the souls of many, and QIȘĀS is there to prevent such development. It is presupposed that if QIȘĀS is not performed, more crimes will occur, which appears to be another entailment of CRIME is SICKNESS metaphor: CRIME may be viral, even endemic.

4.2 Retaining BLOOD: BLOOD is an important cultural symbol that stands metonymically for two things: LIFE and KINSHIP.

wa lā yajib al-qișās illā iḍā tawaffarat aš-šurūṭ al-ātiya: 1 - an yakūn al-maqtūl ma ș̣um ad-dam wa law kāna ḥarbiyan aw zāniyan muḥașșanan aw murtaddan fa-innahu lā ḍamāna 'alā al-qātil lā bi-qiṣāṣ wa lā bi-diya li-anna hā'ulā jamī'an mahdūrū ad-dam ${ }^{59}$

and QIṢĀṢ must not [be done] unless the following conditions are met: 1 - for the slain [one] to be prohibited (infallible, sinless) of blood, and if he were a warrior or an entrenched fornicator or an oppostate, there is no guarantee upon the killer of a retaliation and nor of blood money for those all [are the ones whose] blood [may be] waisted (spilled in vain)

In the above paragraph BLOOD is presented metaphorically as a RESOURCE that should not be wasted (spilled in vain). There are two types of BLOOD: ma șüm and mahdūr. While both terms are semantically rather complex, particularly, the former one ${ }^{60}$, the underlying basic idea that the pair coveys may be

${ }^{58}$ Wehr, H. 1976. A dictionary of modern written Arabic. Edited by J. Milton Cowan. $3^{\text {rd }}$ ed. Ithaca, NY: Spoken Language Services, Inc.; notably the governance model tašaffā $\min$ here is inherited from the verb iqtașa $\min$ (take revenge against smb. - lit. from smb.).

${ }^{59}$ as-Sayyid Sābiq. Fiqh as-Sunna. Dār al-Kitāb al-'Arabī (Egypt), 2002- http://goo.gl/f7gDXk as-Sayyid Sābiq (1915-2000) - the book is one of the major modern sources on Islamic law; as-Sayyid Sābiq (1915-2000) was a well-known Azharite scholar and member of Muslim Brotherhood.

${ }^{60}$ Derivatives of the stem 's- $m$ signify the ideas of (religious) purity, virtue, etc., the $1^{\text {st }}$ form verb meaning 'retain, preserve' however points to the semantic core/source meaning of the stem. 
described as retainable vs. wastable. In light of this opposition, the essential purpose of QIȘĀS is conceived of as retaining BLOOD.

4.3 LIFE: The concept of LIFE features in the most powerful Quranic text often cited as an argument for QIȘĀṢ - wa lakum fì al-qișās hayātun yā ūl al-albāb la 'allakum tattaqūn ('and [there is] for you in QIȘĀṢ life, o owners of minds (i.e. intelligent or reasonable people - A.B.) may you have fear [of God]) ${ }^{61}$. In the example below, LIFE is conceived of as an entity (perhaps a substance) that moves from parent to child. It is a directed movement that has a source (parent is a source of LIFE for the child) and QIȘĀṢ may not reverse this direction by killing (fore-) father in retaliation for a child:

allā yakūn al-qātil aṣlan li-l-maqtūl fa-lā yuqtașșu min wālid bi-qatl waladihi, wa walad waladihi, wa in safila id̄ā qatalahu, bi-ayy wajh min awjuh al-'amd bi-hilāf mā idāa qatala al-ibn aḥad abawayhi, fa-innahu yuqtal ittifāqan, li-anna al-wālid sabab fì hayāt waladihi, fa-lā yakūn waladuhu sababan fì qatlihi wa salbihi al-ḥayāt bi-hilāf mā id̄ā qatala al-walad ahad wālidayhi, fa-innahu yuqtașșu minhu lahumā; ahraja at-tirmid̄i 'an 'umar anna an-nab̄̄ șallā aḷ̣ahu 'alayhi wa sallam qāl: lā yuqtal al-wālid bi-l-walad. ${ }^{62}$

so that the killer not be a source (lit. root) for the killed, and father shall not be retaliated against for the killing of his son and the son of his son, even if he became low (mean, ignoble) when he killed him, by no aspect of premeditation, unlike when the son has killed one of his parents, and he is killed by agreement for the father is cause in the life of his son and his son shall not be a cause in his killing and depriving him of his life unlike if the son has killed one of his parents, and retaliation is [performed] against him for them; at-Tirmidī related [it] from 'Umar that the Prophet, peace be upon him, said 'the father shall not be killed for the son'.

The notion of Parent as a Root (așl) and the Cause of LIFE points to the metaphor of Tree underlying the concept of LIFE. Within this metaphor, LIFE is as a genealogical Tree, which is a directed tree graph, where parents are vertices feeding their offspring through branches, thereby giving LIFE to them. The metaphor of LIFE as TREE is evoked even more clearly in the following definition listed among šurùt al-qișās (conditions of retaliation): an lā yakūn al-maqtūl juz' al-qātil aw min furū'ihi (for the slain [one] not to be part of the slayer or [one] of his branches $^{63}$. The entailment of LIFE as TREE metaphor is that if LIFE has to

${ }^{61}$ Quran 2: 179, translation ours, for a widely accepted English translation see http://quran.com/2 (Saheeh International); most English translations accessible to us appear to be excessively interpretative - adding words that have no basis in the original, e.g. 'legal retribution' in lieu of 'retaliation', 'saving life' or 'basis of life' where we only find 'life' in the original.

${ }^{62}$ This paragraph represents the $5^{\text {th }}$ among 7 conditions (šurūt ) of QIȘĀS according to as-Sayyid Sābiq. Fiqh as-Sunna. Dār al-Kitāb al-'Arabī (Egypt), 2002- http://goo.gl/f7gDXk

${ }^{63}$ al-Mawsū 'a al-Fiqhiyya (Encyclopedia of Islamic Jurisprudence) - http://www.al-islam. com/Loader.aspx?pageid $=1036 \&$ BookID $=510 \&$ TOCID $=23066$ 
go on, the TREE has to continue growing, meaning that direction of the graph cannot be reversed and underlying vertices 'giving life' to one or more braches should be kept in place if even some offshoots may perish. Killing a parent (an underlying vertex) in retaliation for a child (dead offshoot) will be against the principle of growth, i.e. of LIFE proliferation thus conceived.

4.4 POWER: QIȘĀṢ is designed to empower the injured party (the victim or his/her next of kin) against the Offender. There is an explicit reference to this in the Quran, cf.:

wa man qutila maẓlūman fa-qad ja'alnā li-waliyyihi sulțānan fa-lā yusrif fī al-qatli innahu kāna manșūran (Quran 17: 33)

And whoever is killed unjustly, we have given his executor power, but let him not exceed limits in killing. Indeed, he has been supported.

When establishing the responsibility for the crime, the Islamic normative analysis shows awareness of coercion, as an act of power, and distinguishes between the powerful individual who has commissioned the crime and the party that physically carried it out, cf.:

an yakūn al-qātil muḥtāran: fa-inna al-ikrāh yaslub al-irāda wa lā mas'ūliya 'alā man faqad irādatahu fa-ịdā akraha șạhib sulțan gaayrahu 'alā al-qatl fa-qatala ādamiyan bigaayr ḥaqq fa-innahu yuqtal al-āmir dūna al-ma'mūr wa yu'āqab al-ma'mūr. ${ }^{64}$

That the killer has a free will: as coercion deprives of the will and [there is] no responsibility upon whosoever lost his will and if [anyone] vested with power coerced someone else to kill and he killed a human being without right then the one, who ordered [the killing] is to be killed, not the [one who was] ordered and the [one who was] ordered is to be punished.

The overlap between the concepts of QIȘĀS and POWER that characterizes the Islamic normative discourse turns QIȘĀS into a potentially useful asset in the debate for power, if applied in the context of the political discourse.

\section{QIȘĀṢ in the lay public discussion}

In the common parlance, QIȘĀṢ is used in reference to a broad range of cases, which go far beyond the strict requirements of Sharia, cf. a news item titled al-QIȘĀST as-sarī ( (speedy QIȘĀṢ) in an Egyptian newspaper:

${ }^{64}$ This is the $4^{\text {th }}$ condition of QIṢĀṢ according to as-Sayyid Sābiq. Fiqh as-Sunna. Dār al-Kitāb al-'Arabī (Egypt), 2002- http://goo.gl/f7gDXk 
intaqama al-qadr min 'ạțil wa zawjatihi bi-l-manūfiya fa- 'uqba qiyāmihumā bi-s-sațw al-musallaḥ 'alā sā'iq bi-markaz birkat as-sab' wa al-istīlā' 'alā sayyāratihi inqalabat bi-himā as-sayyāra allatī saraqāhā min șāhịihīā wa tamm naqluhumā ilā al-mustašfă ${ }^{65}$

The fate has avenged an unemployed and his wife in Manufiya after they had performed an armed assault on a driver in the center of Birkat as-Sab ' and have taken possession of his car, the car that they had stolen from its owner turned over on them and they were transported to the hospital. ${ }^{66}$

Nothing in this situation fits the strict conditions (šurüt al-qișass ) as described in the Sharia books. QIȘĀSS here is not part of a normative judgment but rather an expression of the author's satisfaction that the offenders have been duly punished, it conveys a meaning that in English would be expressed by such idioms as 'what goes around comes around', 'harm set, harm get', 'meet/get/obtain one's deserts' etc. The use of the verb intaqam (avenge) in the text titled 'Qișāṣ' is also quite notable, as it indicates that the contrast between the concepts of ITIQĀM and QIȘĀṢ emphasized in the Islamic normative discourse may be easily neutralized in the lay discussion.

In the lay discourse, the concept of QIȘĀṢ is linked not only to LIFE in a biological sense, i.e. LIFE as opposed to DEATH or the idea of the preservation of human species, but also to the notion of everyday LIFE - i.e. normal functioning of people in their habitual social environment and by extension the very notion of normalcy whose restoration in the aftermath of a violent crime calls for an immediate act of QIȘĀṢ. Cf.:

akkada aḥmad nājī mudarrib ḥurrās marmā al-farīq al-awwal li-kurat al-qadam bi-n-nādī al-ahalī 'alā șu'ūbat at-tadrībāt allatī sa-yahūụuhā al-lā'ibūn ma'a isti'nāf an-nišâț ar-riyāḍ̄i yawm al-jum'a al-muqbil ba'd majzarat būr sa'īd. wa ašāra nājī ilā anna al-farīq yahūụ tadrībātahu wasat ajwă' șa 'ba wa hâala nafsiya sayyi'a lan tahda' illā ma 'a al-qișās bi-aqșā sur ' $a^{67}$

Ahmad Naji, coach of goalkeepers of the first football team at the al-Ahli club has pointed out the difficulty of exercises that the players will conduct with the resumption of sporting activities next Friday after the slaughter of Port Said. And Naji pointed out that the team is conducting its exercises in the midst of difficult atmosphere and bad psychological state [which] will not calm down unless QISTĀST [is performed] at the highest speed.

\footnotetext{
${ }^{65} \mathrm{http}: / /$ digital.ahram.org.eg/Accidents.aspx?Serial=1090626

${ }^{66}$ The news article then goes on to describe the police interference in the case.
}

${ }^{67} \mathrm{~A}$ news article published in Wafd newspaper on 14.02.2012 (i.e. four month before the presidential elections, when the military government that took power in the aftermath of the January 25 revolution was still in full swing) titled 'Nājī: lā budda min al-qișāṣ fì asra' waqt' (Naji: it is necessary [to perform] qișās in the nearest time' accessible through the news integrator Masress - http://www.masress.com/alwafd/162776 
Our next example, despite the Quranic quotation meant to make it sound more convincing, seems to express the same idea - QIȘĀṢ will ensure the return to normalcy and psychological relief:

fa-naḥnu jamī'an ma'a at-țuwār aš-šubbān aš-šurafâ’ al-anqiyā’ fī mațālib al-qișāṣ al-'ādil mim-man irtakabū jarā'im qatl wa sirqa wa ihdār li-l-māl al-‘āmm wa nurīduhu qaț'an qiṣāșan sarī'an hattā tahda' al-ḥawâțir wa tartāḥ an-nufūs wa lakum fī-l-qișāṣi hayātun yā ūīi al-albāb ${ }^{68}$

And we all [are] [together] with young noble and pure revolutionaries in [their] demands for the just QIȘĀS against [those] who have committed crimes of murder and theft and squandering the public funds and we want it definitely [to be] a speedy QIȘĀṢ in order for the thoughts to calm down and for the souls to rest "and [there is] for you in QIȘĀṢ life, o owners of minds" 69

Notably two of three crimes mentioned in this example do not qualify for QIȘĀS in strict Sharia terms, which are limited to violent crimes (murder and bodily injury), murder is however opening the sequence.

Perhaps the most essential common element shared by both the religiously inspired and lay discourses is the idea of (psychological) relief and social peace as the natural outcome, or even the purpose of QIȘĀS. The idea of immediacy/speediness as an immanent characteristic of QIȘĀS does not come out explicitly in the Islamic discourse on QIȘĀST, but the healing/soothing quality ascribed to QIȘĀS by the Islamic normative tradition appears to be quite coherent with this idea, as is the metaphor GAYZ (ANGER) is FIRE, which we have discussed above.

Another idea common to both the Islamic and lay discourses is that QIṢĀṢ is the best, if not the only, method of preventing ${ }^{70}$ further crimes, which goes along with the presupposition that crime has a natural tendency to spread - like a sickness spreads in a community - unless prevented, while the best prevention method is essentially to give the offender a taste of his own medicine., cf.:

qaddam hiizb šabāb mișr hnāliṣ al-'azā' li-jumū' aš-ša'b al-mișrī fì ḍaḥāyā al-mawja al-infijāriya allatī țālat amākin 'adīda fī al-'āṣima al-miṣriya șabāḥ al-yawm al-jum'a (...) mu'akkidan 'alā ḍarūrat taškīl maḥākim institnā'iya li-l-irhābiyīn li-tuṣdir ạ̣kāmahā bi-šakl 'ājil wa sarī' 'abra aḥkām rādi'a li-kull man tusawwil lahu nafsuhu al-masās bi-amn miṣr ${ }^{71}$

${ }^{68}$ From an article published in al-Ahrām newspaper on 17 July 2011 titled kalimat haqq (A Word of Truth) - http://www.ahram.org.eg/archive/Columns/News/90086.aspx

${ }^{69}$ Quran 2: 179

${ }^{70}$ To express this meaning derivatives of the root $r d^{\text {' }}$ are used in lay discourses rather than $z j r$ as in 2.1.

${ }^{71}$ A news article dated 24 January 2014 - http://horytna.net/Articles/Printdetails.aspx?AID= 95094\&ZID= 
Egypt Youth Party has presented its sincere condolences to all the Egyptian people in [respect of] the victims of a wave of explosions which affected numerous places in the Egyptian capital on this Friday morning (...) having stressed the need for the formation of emergency courts for the terrorists in order to issue their verdicts in a speedy and immediate fashion through preventive verdicts for anyone who would be tempted (lit. whose soul would seduce him) to compromise the security of Egypt.

Although QIȘĀS is not mentioned explicitly in this segment, the argument is shaped by key ideas associated with it - the speediness/immediacy, prevention meant to forestall the perceived natural tendency of crime to spread.

\section{Conclusions}

The Islamic normative and lay discourses differ in the referential scope of QIṢĀṢ. In contrast to Islamic normative discourse, the lay discourses often mix up the notions of INTIQĀM (REVENGE) and QIȘĀS. The originally relatively narrow Islamic legal term, specifying punishment only for the violent crimes, QIṢĀṢ has colonized most of the lay discussion on crime and morality operating as universal standard for how justice is expected to be delivered. QIȘĀS has become the embodiment of the idea of natural (also God's prescribed) justice. QIṢĀṢ is essentially egalitarian as it is meant to re-instate a sense of balance in the community and to give everyone their due by privileging the Victim and his/her next of kin and empowering them against the Offender. By way of contrast, 'ADĀLA (JUSTICE), associated with the formal institutions of power, is a non-egalitarian concept ${ }^{72}$. The Egyptian revolutionary discourse reflects a growing tension between the two concepts. By privileging QIȘĀS and making it their key demand, the revolutionaries challenged the powers that be and their slow and inhumane JUSTICE system.

Three ideas associated which QIȘĀṢ, located, from the formal point of view, on the periphery of its frame semantic structure, are shared across both the Islamic normative and lay discourses and constitute an essential part of the local belief system: (a) QIȘĀS means relief from negative feelings for both the individual and the group; (b) QIȘĀṢ should be performed in a speedy fashion; and (c) QIṢĀS is the best method of preventing more crime. These ideas appear to be closely linked to each other thus forming a neat conceptual unity. Another significant element of the frame-semantic structure underlying the concept is its link to the concept of POWER. In the context of a large scale political con-

${ }^{72}$ In that sense it appears to be similar to the way Wierzbicka describes the pre-modern Anglo notion of Justice, cf. Wierzbicka, A. 2006. English: meaning and culture. Oxford: Oxford University Press. $158-159$. 
frontation, the idea that the injured party, i.e. potentially anyone, every common person, may be empowered against the offender, has converted this Islamic legal concept into a potent instrument of the revolutionary struggle. It is this idea that is the source of an exceptional illocutionary force associated with the concept and the reason, why it has acquired such popularity as a slogan of the Egyptian Arab Spring. The argument around QIȘĀṢ, a shared value for all parts of the Egyptian society, its promptness or appropriateness has become a dispute for power. By calling on the authorities to submit to people's will and threatening with a people's QIȘĀṢ, the revolutionaries were affectively staging a symbolic offensive against the government. 